Bull. Fac .Agric., Cairo Univ. 64:396-408 (2013).

\title{
CHEMICAL AND BIOLOGICAL STUDIES ON SOME POMEGRANATE PRODUCTS
}

(Received: 3.12.2013)

\author{
By \\ S. A. Arafa \\ Special Food and Nutrition Department, Food Technology Research Institute, Agricultural Research \\ Center, Giza, Egypt.
}

\begin{abstract}
Pomegranate fruit is widely used in food and processing industries due to its excellent nutritional and health value. Therefore, the aim of the present study was to produce pomegranate molasses by different methods and jam from pomegranate fruit arils, and measure the main quality characteristics of these products. Also, to study the effect of these products on general antioxidative status and some immune parameters in healthy young rats.

It was found that pomegranate molasses produced by rotary with sugar and pomegranate jam achieved the highest scores for overall acceptability compared with other samples. Total soluble solids of pomegranate molasses produced by rotary with sugar were higher than the other pomegranate molasses as a result of sugar addition. Meanwhile, pomegranate molasses produced by heating method showed the lowest values for all color indices compared with other products as a result of severe heat treatment. Pomegranate molasses contained higher levels of $\mathrm{Fe}, \mathrm{Zn}$ and $\mathrm{Ca}$ than juice. Pomegranate molasses produced by rotary without sugar contained the highest polyphenols $(18.93 \pm 0.63 \mathrm{mg} / 100 \mathrm{~g})$ and total flavonoids ( $44.71 \pm 3.54 \mathrm{mg} / 100 \mathrm{~g}$ ) levels with the highest antioxidant activity.

Feeding healthy young rats on different pomegranate products caused significant reduction in liver marker enzymes AST and ALT activities but significant increase in glutathione peroxidase activity (GPx) in serum of rats relative to the control. The highest elevation in GPx activity was achieved by feeding group rat on pomegranate molasses produced by rotary without sugar at $11.75 \%$. Also, feeding rats on different pomegranate products caused significant increase in the levels of serum iron, $\operatorname{IgM}$ and $\operatorname{IgG}$ levels. From the present results it could be concluded that, pomegranate molasses produced by rotary methods achieved the highest quality characteristics compared with other pomegranate products. Pomegranate products could be used in many foods and products to improve general antioxidative status and immune functions due to its many bioactive compounds.
\end{abstract}

Key words: antioxidant activity, bioactive compounds, healthy rats, immune functions, jam, molasses, pomegranate.

\section{INTRODUCTION}

Considerable importance is given to functional foods which a part from their basic nutritional functions, provide physiological benefits and play an important role in disease prevention or slow the progress of chronic diseases. There has been much more interest in pomegranate as a medicinal and nutritional product because of its multifunctionality and its great benefit in the human diet due to its several groups of substances which are useful in disease risk treatment(Jaiswal et al., 2010).

Pomegranate (Punica granatum L., Punicaceae) is one of the oldest edible fruits native to the area of Iran to the Himalayas in northern India, and has been cultivated and naturalized over the entire Mediterranean region. The edible parts of pomegranate fruit are consumed fresh or used for the preparation of fresh juice, canned beverages, jelly, jam, paste and also for flavoring and coloring beverage products. The edible part of the fruit $(50 \%)$ consists of $40 \%$ arils, which are used to obtain the juice, and $10 \%$ seeds. Arils contain $85 \%$ water, $10 \%$ total sugars, mainly fructose and glucose, $1.5 \%$ pectin, organic acids such as ascorbic, citric and malic acids, bioactive compounds such as phenols and flavonoids, principally anthocyanins (Mousavinejad et al., 2009 and Tezcan et al., 2009).

Pomegranate aril juice is primarily considered as an important source of phenolic compounds: 
the soluble polyphenol content varies from 0.2 to $1.0 \mathrm{~g} / 100 \mathrm{~g}$,dry weight being anthocyanins one of the most important. Together with lignans, gallayl-type tannins, ellagic acid derivatives and other hydrolysable tannins which contribute to the antioxidant activity of the juice. Pomegranate juice possessed a 3-folds higher antioxidant activity than that of green tea, and 2-, 6- and 8folds higher levels than those detected in grape or cranberry, grapefruit and orange juices, respectively (Gil et al., 2000 and Rosenblat and Aviram, 2006). Seeram et al. (2008) reported that, pomegranate juice had the greatest antioxidant potency composite index among such beverages as apple, black cherry, blueberry, cranberry, grape, orange juices and iced tea and the antioxidant activity was at least $20 \%$ greater than any of the other beverages tested.

Pomegranate molasse is a thick syrup made from cooked-down pomegranate juice, which is a slightly astringent, sweet-sour condiment that is deep and dark (and slightly ruby) in color. Production of pomegranate molasses typically includes cleaning and crushing of pomegranates, extraction, filtration, clarification and concentration of pomegranate juice in open vessel or molasses have had various applications as a flavoring agent, a salad dressing or soft drink ingredient. Pomegranate molasses may have 2 to 3 fold higher mineral components and antioxidant content than fresh pomegranate juice (Maskan, 2006 and Yilmaz et al., 2007).

Pomegranate fruit could be considered a functional food because it has valuable phytochemicals that display medicinal effects. These can act as antioxidant, anti-hepatotoxic, antimicrobial, anti-inflammatory and anti-diabetic and improve cardiovascular health (Duman et al., 2009 and Lee et al., 2010). Polyphenols as dietary antioxidants may affect various aspects of both innate and adaptive wings of the immune system by shifting pro-oxidant/antioxidant balance. Complement system, for instance, has been shown to be inhibited by polyphenols and this complement inhibitory effect may have some role in anti-inflammatory properties of polyphenols. Pomegranate rich concentration of diverse, freeradical scavenging bioflavonoids, made it recommended in the treatment of acquired immune deficiency syndrome (Moneim et al., 2011).

Therefore, the aim of this study was to produce pomegranate juice, molasses by different methods and jam from pomegranate fruit. Evaluation of the new products through measuring the main quality of these products. Also, to study the effect of these products on general antioxidant status and some immune parameters in healthy young rats.

\section{MATERIALS AND METHODS}

\subsection{Materials}

Fresh pomegranate fruits (Punica granatum L., Punicaceae, variety Sukary) were purchased from the local market of Giza Governorate, Egypt. Chemicals were obtained from Sigma Chemical Co. (St. Louis, MO, USA) and common commercial suppliers.

\subsection{Methods}

\subsubsection{Technological studies}

\subsubsection{Preparation of pomegranate juice}

Pomegranate fruits were washed in tap water and drained. They were manually cut-up and the outer leathery skin (peel) which encloses hundreds of fleshy arils was removed. The juice that is localized in the arils was manually pressed and extracted. The obtained aril juice had a deep-red color was stored at $4^{\circ} \mathrm{C}$ overnight for settling suspended particles, then filtered and stored at $20^{\circ} \mathrm{C}$ for further analysis.

\subsubsection{Preparation of pomegranate molasses}

Two different (heating/evaporation) processes were employed for the production of pomegranate juice concentrate (molasses). The juice was concentrated to a final $60.5^{\circ}$ Brix from an initial $17.5^{\circ}$ Brix by the following evaporation processes:

1- Evaporation at atmospheric pressure: The pomegranate juice was concentrated by using an electromagnetic heater (PYRO MUI TiMagnestir). The juice sample $(500 \mathrm{ml})$ was placed in a beaker and replaced on the heater open to atmosphere. The sample was continuosly heated and stirred during this process. Samples were taken for measurement of ${ }^{\circ}$ Brix and replaced again after use.

2- Evaporation by using rotary vacuum evaporator: The juice sample $(500 \mathrm{ml})$ was concentrated in a laboratory rotary vacuum evaporator (RE 100 Model, Bibby Sterilin Ltd., England) rotating at $66 \mathrm{rpm}$ and $40^{\circ} \mathrm{C}$. Samples were taken from the bulk of juice periodically for measurement of ${ }^{\circ}$ Brix and replaced again after used. Sugar was added to a part of pomegranate juice before production of pomegranate molasses produced by rotary evaporator to obtain pomegranate molasses with or without sugar.

\subsubsection{Preparation of pomegranate low-sugar jam \\ Pomegranate jam was prepared according to}


the procedure described by Poiana et al. (2012) with some modifications. Pomegranate juice $(450 \mathrm{~g})$ was blended and then cooked under atmospheric pressure with the addition of sucrose $(247 \mathrm{~g})$. Pectin was added at a concentration of $1 \%$ at the final stage of jam cooking. Citric acid was added towards the end of cooking for adjusting $\mathrm{pH}$ value to $\mathrm{pH} 3$. Time of thermal processing was about $25 \mathrm{~min}$. at $80^{\circ} \mathrm{C}$ until the final product reached $45^{\circ}$ Brix. The jam was filled into hot glass jars, capped and pasteurized at $80^{\circ} \mathrm{C}$ for $10 \mathrm{~min}$., it was allowed to cool at room temperature and stored in the dark until analysis.

\subsubsection{Physical analysis}

Total soluble solids (T.S.S.) content of pomegranate juice, molasses and jam were determined by using an Abbe refractometer (Bellingham Stanley Limited) at $20^{\circ} \mathrm{C}$ and expressed in degrees of Brix. $\mathrm{pH}$ was measured by means of a $\mathrm{pH}$ meter (Jenway, Staffordshire, United Kingdom). Titratable acidity was measured by titration to an endpoint of $\mathrm{pH} 8.2$ using a Metrohm 862 compact titrosampler (Herisau, Switzerland). ACR-300 chroma meter (Minolta, Osaka, Japan) was used for color measurements. The instrument was calibrated with a white standard tile $\left(\mathrm{L}^{*}=97.43, \mathrm{a}^{*}=-0.01, \mathrm{~b}^{*}=1.64\right)$. A glass beaker containing the samples was placed below the light source.

\subsubsection{Chemical analysis}

Protein and ash contents of pomegranate products were determined according to A.O.A.C. (2006). Total and reducing sugars were measured as described by Melgarejo et al. (2000) with some modifications. Total phenolic contents of pomegranate juice, molasses and jam were determined according to Singelton et al. (1999) using Folin-Ciocalteu reagent and gallic acid as standard and the results expressed as mg gallic acid equivalent $/ 100 \mathrm{ml}$. Free-radical scavenging activity of the tested samples against stable 2,2diphenyl-1-picrylhydrazyl (DPPH) assay was performed according to the method described by Karioti et al. (2004). Total flavonoids were measured spectrophotometrically at $510 \mathrm{~nm}$ and expressed as $\mathrm{mg}$ gallic acid equivalents $/ 100 \mathrm{ml}$ according to Yang et al. (2009). Mineral elements $(\mathrm{K}, \mathrm{Ca}, \mathrm{Mg}$ and $\mathrm{Fe}$ ) were determined in the samples using a Perkin Elmer Optima 2100 DV model (Shalton, USA) coupled with plasma spectrometer according to Barnes (1997).

\subsubsection{Sensory evaluation}

Pomegranate juice, molasses and jam samples were evaluated by ten trained panelists from Food Technology Research Institute, Giza, Egypt. The evaluated sensory characteristics included appearance, texture, taste, color and odor using a 10-point hedonic scale ranging from extremely dislike (1) to extremely like (10) according to Saka et al. (2007).

\subsubsection{Biological studies}

\subsubsection{Animals and experimental diets}

A total of 36 Sprague-Dawley male rats were obtained from Ophthalmology Research Institute, Giza, Egypt. The rats weighing $150 \pm 5 \mathrm{~g}$ were housed in plastic cages and fed on basal diet and water for one week (adaptation period). The basal diet composed of casein (15\%), cellulose $(5 \%)$, vitamin mixture $(1 \%)$, salt mixture $(4 \%)$, corn oil $(10 \%)$ and corn starch (65\%) according to Zamora et al. (1991). The rats were divided into 6 groups $(n=6)$. The first group was fed on basal diet and considered as a control. The other five groups of rats were orally administered with $3 \mathrm{ml} \backslash \mathrm{Kg}$ of pomegranate juice, molasses and jam samples according to the results mentioned in animal studies (Moneim et al., 2011) and given for each rat once daily before meals. Blood samples were taken from orbital plexus venous from fooddeprived rats for $12 \mathrm{~h}$. and the serum was separated and stored at $-20^{\circ} \mathrm{C}$ for analysis.

2.2.2.2. Biochemical analysis: Serum glutathione peroxidase (GPx) activity was estimated according to the method described by Daret and Ching (1996). Aspartate aminotransferase (AST) and alanine aminotransferase (ALT) activities were determined colorimetrically according to the method described by Bergmeyer and Harder (1986). Iron levels in serum were measured by the method mentioned by Seigin, (1977). Serum samples for measurement of antigen-specific IgM and $\mathrm{IgG}$ titers were prepared and analyzed by an immulon 4 enzyme linked immunosorbent assay (ELISA) kits (Dynex Technologies, Inc., Chantilly) as described by Deisenhammer et al. (1996). Hemoglobin concentration and blood cell counts were performed on the EDTA-treated blood according to the method of Craven et al. (1992).

\subsubsection{Statistical analysis}

The standard analysis of variance procedure in a completely randomized design was applied for the present data according to Gomez and Gomez (1984).

Least significant difference (LSD) test was to compare a pair of group means. The level of statistical significance was set at $\mathrm{P}<0.05$.

\section{RESULTS AND DISCUSSION 3.1. Technological studies}




\subsubsection{Sensory evaluation of pomegranate products}

The sensory characteristics, i.e., appearance, texture, taste, color and odor of pomegranate products were evaluated by ten panelists. The overall acceptability was calculated and the obtained data were statistically analyzed and shown in Table (1). Pomegranate molasses obtained from the local market as a control were used for the comparison with the research pomegranate products. However there was no pomegranate jam in the local market to be used as a control for pomegranate jam produced in the present study. Pomegranate molasses produced by rotary with sugar achieved the highest scores for different sensory attributes compared with all other products examined in the present study. There were non - significant differences between the control pomegranate molasses by rotary without sugar and pomegranate juice for appearance, texture and color. Control pomegranate molasses were not significantly different for texture compared with pomegranate molasses produced by rotary with sugar. The highest score was recorded for the control pomegranate molasses and pomegranate molasses produced by rotary with sugar which were significantly different compared with other products, followed by pomegranate juice, pomegranate molasses produced by rotary without sugar and pomegranate molasses produced by heating, respectively.

Astringency is known to play an important role in pomegranate juices with elevated phenolic contents. The consumption of strongly astringent food causes saliva protein denaturation and may markedly impair taste bud sensation. In the present study, all products produced from pomegranate juice obtained from pomegranate arils had intermediate phenolic contents than peels and seeds. The juices were assessed with regard to their visual appearance, bitterness and typical pomegranate flavor. Pomegranate juices showed significant differences among them for all sensory parameters except for aroma, which might point out that aroma is not a distinctive sign of pomegranate juice, while color and taste have been reported as crucial for the attractiveness of red fruits (Fischer et al., 2011).

\subsubsection{Physical characteristics of pomegranate products}

Data presented in Table (2) show the physical characteristics of pomegranate juice, pomegranate molasses and pomegranate jam. These characteristics including: total soluble solids, acidity, $\mathrm{pH}$ and color. It could be observed that, there was significant difference between pomegranate products in total soluble solid contents but pomegranate jam contained the highest total soluble solids $\left(55.4 \pm 2.95^{\circ}\right.$ Brix $)$ as a result of high concentration during processing, while fresh pomegranate juice contained the lowest total soluble solids $\left(13.5 \pm 0.98^{\circ}\right.$ Brix $)$. Total soluble solids for pomegranate molasses produced by rotary with sugar were higher compared with other pomegranate molasses as a result of sugar addition. Acidity was significantly higher in pomegranate jam compared with other products. On the other hand, fresh pomegranate juice and molasses produced by rotary with sugar were not significantly different compared with each other for acidity characteristic. Regarding pomegranate products, $\mathrm{pH}$ value of pomegranate jam was significantly lower than those of the other pomegranate products.

From Table (2) it could be found that, pomegranate juice and molasses produced by rotary with sugar were not significantly different for color indices of lightness $\left(\mathrm{L}^{*}\right)$, while pomegranate molasses produced by heating and by rotary without sugar were not different for $\left(\mathrm{L}^{*}\right)$ value. Redness $\left(a^{*}\right)$ values were significantly

Table (1): Sensory evaluation of pomegranate products.

\begin{tabular}{|l|c|c|c|c|c|c|}
\hline \multicolumn{1}{|c|}{ Samples } & $\begin{array}{c}\text { Appearance } \\
(\mathbf{1 0})\end{array}$ & $\begin{array}{c}\text { Texture } \\
(\mathbf{1 0})\end{array}$ & $\begin{array}{c}\text { Taste } \\
\mathbf{( 1 0 )}\end{array}$ & $\begin{array}{c}\text { Color } \\
\mathbf{( 1 0 )}\end{array}$ & $\begin{array}{c}\text { Odor } \\
(\mathbf{1 0})\end{array}$ & $\begin{array}{c}\text { Overall } \\
\text { acceptability } \\
(\mathbf{5 0})\end{array}$ \\
\hline Pomegranate juice & $8.9^{\mathrm{ab}}$ & $8.2^{\mathrm{c}}$ & $8.7^{\mathrm{b}}$ & $8.9^{\mathrm{ab}}$ & $8.3^{\mathrm{b}}$ & $43.0^{\mathrm{b}}$ \\
\hline Control PM & $8.6^{\mathrm{b}}$ & $9.3^{\mathrm{a}}$ & $9.1^{\mathrm{a}}$ & $8.3^{\mathrm{c}}$ & $8.6^{\mathrm{ab}}$ & $43.9^{\mathrm{b}}$ \\
\hline PM by heating method & $7.1^{\mathrm{c}}$ & $8.4^{\mathrm{bc}}$ & $6.8^{\mathrm{c}}$ & $6.4^{\mathrm{d}}$ & $6.7^{\mathrm{c}}$ & $35.4^{\mathrm{c}}$ \\
\hline PM by rotary with sugar & $9.4^{\mathrm{a}}$ & $9.3^{\mathrm{a}}$ & $9.3^{\mathrm{a}}$ & $9.5^{\mathrm{a}}$ & $9.0^{\mathrm{a}}$ & $46.5^{\mathrm{a}}$ \\
\hline PM by rotary without sugar & $8.6^{\mathrm{b}}$ & $8.7^{\mathrm{b}}$ & $8.6^{\mathrm{b}}$ & $8.9^{\mathrm{b}}$ & $7.4^{\mathrm{cd}}$ & $42.2^{\mathrm{b}}$ \\
\hline pomegranate jam & $8.5^{\mathrm{b}}$ & $8.8^{\mathrm{b}}$ & $7.9^{\mathrm{e}}$ & $9.1^{\mathrm{a}}$ & $8.5^{\mathrm{ab}}$ & $42.8^{\mathrm{b}}$ \\
\hline L.S.D. & 0.53 & 0.43 & 0.52 & 0.55 & 0.61 & 2.06 \\
\hline
\end{tabular}

*PM = pomegranate molasses produced.

*Numbers in the same column with the same letters were not significantly different at $\mathrm{P}<0.05$. 
Table (2): Total soluble solids, acidity, pH and color measurements of pomegranate products.

\begin{tabular}{|l|c|c|c|c|c|c|}
\hline \multicolumn{1}{|c|}{ Physical properties } & $\begin{array}{c}\text { Total soluble } \\
\text { solids } \\
(\%)\end{array}$ & Acidity & pH & \multicolumn{3}{c|}{ Color parameters } \\
\cline { 5 - 8 } & & & $\mathbf{L}^{*}$ & $\mathbf{a}^{*}$ & b* $^{*}$ \\
\hline Pomegranate juice & $13.5 \pm 0.98^{\mathrm{e}}$ & $0.679 \pm 0.15^{\mathrm{d}}$ & $3.44 \pm 0.06^{\mathrm{b}}$ & $17.59 \pm 0.83^{\mathrm{a}}$ & $7.10 \pm 0.22^{\mathrm{a}}$ & $11.32 \pm 0.74^{\mathrm{b}}$ \\
\hline PM by heating method & $30.5 \pm 1.06^{\mathrm{d}}$ & $1.091 \pm 0.19^{\mathrm{c}}$ & $3.50 \pm 0.08^{\mathrm{b}}$ & $14.19 \pm 0.74^{\mathrm{b}}$ & $1.82 \pm 0.21^{\mathrm{d}}$ & $6.55 \pm 0.36^{\mathrm{c}}$ \\
\hline PM by rotary with sugar & $38.0 \pm 2.53^{\mathrm{b}}$ & $0.627 \pm 0.13^{\mathrm{d}}$ & $3.67 \pm 0.10^{\mathrm{a}}$ & $17.89 \pm 0.95^{\mathrm{a}}$ & $6.44 \pm 0.36^{\mathrm{b}}$ & $12.09 \pm 0.55^{\mathrm{a}}$ \\
\hline PM by rotary without sugar & $34.0 \pm 1.48^{\mathrm{c}}$ & $1.360 \pm 0.28^{\mathrm{b}}$ & $3.81 \pm 0.07^{\mathrm{a}}$ & $14.47 \pm 0.62^{\mathrm{b}}$ & $4.21 \pm 0.29^{\mathrm{c}}$ & $10.77 \pm 0.42^{\mathrm{b}}$ \\
\hline Pomegranate jam & $55.4 \pm 2.95^{\mathrm{a}}$ & $2.100 \pm 0.32^{\mathrm{a}}$ & $3.05 \pm 0.06^{\mathrm{c}}$ & N.D. & N.D. & N.D. \\
\hline L.S.D. & 2.36 & 0.24 & 0.15 & 0.46 & 0.52 & 0.63 \\
\hline
\end{tabular}

$* \mathrm{PM}=$ pomegranate molasses produced.

*Numbers in the same column with the same letters were not significantly different at $\mathrm{P}<0.05$.

N.D. = not detected.

different between different pomegranate products. The present results revealed that pomegranate molasses produced by rotary evaporation with sugar, achieved the highest values for color attributes $\left(\mathrm{L}^{*}, \mathrm{a}^{*}\right.$ and $\left.\mathrm{b}^{*}\right)$ compared with other pomegranate molasses. Meanwhile, pomegranate molasses by heating method showed the lowest values for all color indices as a result of severe heat treatment. Color indiex values were not detected in pomegranate jam because of high viscosity and concentration of the product.

The present results are in good agreement with the results mentioned by Rinaldi et al. (2013) who found that, pomegranate juice obtained from 100 $\mathrm{g} / 100 \mathrm{~g}$ of arils showed $\mathrm{pH}$ value of $3.46 \pm$ 0.01 acidity of, $0.68 \pm 0.01 \mathrm{~g} / 100 \mathrm{ml}$ and $13.75 \pm$ $0.06^{\circ}$ Brix total soluble solids. The $\mathrm{pH}$ of pomegranate molasses comes predominantly from the organic acids of pomegranate fruits .The present results are higher than those reported by Vardin et al. (2008) who determined $\mathrm{pH}$ of the pomegranate juice concentrate as 1.34 to 2.90 . The variation in the acidity values of pomegranate molasses may be due to the evaporation methods applied in the production of molasses.

The red, blue and orange color in flowers, fruits and vegetables is due to anthocyanins, these have to be accounted for in processing. These compounds must be preserved during fruit juice processing, because they exert health protective effects for human (Vardin and Fenercioglu, 2003). Since $\left(\mathrm{L}^{*}\right)$ value is a measure of the color in the light-dark axis, the reduce in this value indicates that the pomegranate molasses of the present study were turning darker. The decreases in $\left(\mathrm{L}^{*}\right)$ value correlated well with the increases in the browning of food materials and pigment destruction (Ahmed et al., 2004). Our results are in agreement with the results of Patras et al. (2010), who observed decreasing values in Hunter $\left(\mathrm{a}^{*}\right)$ parameter as a result of the thermal treatment of strawberry and blackberry purees at $70^{\circ} \mathrm{C}$. Because pomegranate molasses are concentrated products of pomegranate juice, lab color values correspond to dark, slightly red and blue in color.

\subsubsection{Chemical composition of pomegranate products}

Table (3) shows the chemical composition of pomegranate juice, molasses and jam products including: total sugars, reducing sugars, protein and ash contents. Total sugars were significantly different in all pomegranate products with the highest content found in pomegranate molasses produced by the heating method followed by pomegranate jam. Fresh pomegranate juice contained a lower value of total sugars than those of other products. Reducing sugars content was not significantly different for pomegranate molasses produced either by heating or rotary without sugar, while fresh pomegranate juice and pomegranate jam were not significantly different in reducing sugar content. Evaporation of water during the production of molasses increases the concentration of carbohydrates in the final product.

Suh et al. (2003) reported that, sugar and sugar degradation products have been found to be effective on accelerating anthocyanin (pomegranate pigment) breakdown and enhance non-enzymatic browning during thermal processing. Poyrazoglu et al. (2002) found total sugars of $148.75 \mathrm{~g} / \mathrm{l}$ by analyzing freshly squeezed pomegranate juice of 13 different types. A significant part of the total sugars content was subjected to inversion through thermal processes. There was non- significant difference between pomegranate molasses produced by heating or rotary with sugar in protein content. Meanwhile 
protein content of fresh pomegranate juice and pomegranate molasses produced by rotary without sugar was not significantly different (Table 3). Ash content was not statistically different between pomegranate molasses produced by rotary either with or without sugar. Filtration and clarification of pomegranate juice during commercial processing may be the main reason for low protein and ash contents of pomegranate molasses. According to Anonymous (2006). The protein content of pomegranate was $0.95 \mathrm{~g} / 100 \mathrm{~g}$ and the protein content of some samples increased through concentration of the products, while some decreased through denaturation of proteins during heating treatments.

\subsubsection{Mineral composition of pomegranate products}

Data presented in Table (4) show the mineral composition $(\mathrm{Fe}, \mathrm{Ca}, \mathrm{Mg}$ and $\mathrm{K}$ ) of pomegranate products. Fresh pomegranate juice contained lower $\mathrm{Fe}, \mathrm{Ca}, \mathrm{Mg}$ and $\mathrm{K}$ contents compared with other pomegranate products. Pomegranate molasses produced by rotary without sugar contained the highest mineral contents followed by pomegranate molasses with sugar. The present results are in agreement with those reported by Fadavi et al. (2005) who found that, pomegranate juice contained lower levels of $\mathrm{Fe}, \mathrm{Zn}$ and $\mathrm{Ca}$ than pomegranate molasses, which is a good source of various minerals. It was revealed that pomegranate molasses was richer in minerals than the fruit itself. However, the results showed that in the concentrated product the mineral contents of pomegranate juice were variously affected by the concentration process. Incedayi et al. (2010) found that, pomegranate molasses were rich in minerals, especially potassium (450-4700 $\mathrm{mg} / 100 \mathrm{~g})$, calcium $(71.88-1803.63 \mathrm{mg} / 100 \mathrm{~g})$, magnesium (7.48-409.10 $\mathrm{mg} / 100 \mathrm{~g})$ and iron (1.05- $22.99 \mathrm{mg} / 100 \mathrm{~g}$ ).

\subsubsection{Polyphenols, total flavonoids and antioxidant values of pomegranate products}

Polyphenolic compounds give the color, astringency and bitter taste to pomegranate juice. Also these compounds cause cloudiness during the concentration process and storage (Alper et al., 2005). Since pomegranate molasses is a concentrated product, it was anticipated that the phenolic substances would increase in percentage despite the losses during thermal processing. Pomegranate molasses produced by heating method contained the lowest polyphenols and total flavonoids contents compared with other products, while pomegranate molasses produced by rotary without sugar contained the highest polyphenols and flavonoid contents (Table 5). There was non significant difference between pomegranate molasses produced by rotary with sugar and pomegranate jam in polyphenol content but there was a significant difference between fresh pomegranate juice and the produced molasses by rotary with sugar or jam in total flavonoid contents. Also, non significant difference was found between fresh pomegranate juice and molasses produced by rotary with sugar or jam in total flavonoid contents. The increase in total phenols and total flavonoids content of pomegranate molasses is mostly due to the evaporation of water during processing. From the technological point of view and owing to their biological properties, the greatest importance among all phenol compounds present in pomegranate juices is considered to be due to ellagic acid derivatives, punicalagins and anthocyanins. Total phenol content was indicating considerable variations among pomegranate juices since the levels differed between 1500 and 4500 mg gallic acid equivalent/l (Mena et al., 2011).

Antioxidant activity of pomegranate products measured by DPPH method revealed that, pomegranate molasses produced by rotary with and without sugar were not significantly different in antioxidant activity and both achieved the highest antioxidant activity compared with other products. The lowest antioxidant activity was found in pomegranate molasses produced by traditional heating method as a result of the long term thermal processing which caused lower antioxidant activity. Orak (2008) determined the antioxidant activities of pomegranate juice and molasses which were $79.06 \%$ and $85.91 \%$, respectively, these are in accordance with the present results. The high value of antioxidant activity of pomegranate molasses may be due to the phenolic content in spite of anthocyanin being destroyed by the effect of heating. Pomegranate fruit is a rich source of polyphenols which ranged from $290-450 \mathrm{mg} / 100 \mathrm{ml}$ juice and the total flavonoids contents were significantly different between pomegranate cultivars with approximately 1.6-folds difference between the highest and the lowest contents (Fawole et al., 2011). Vrhovsek et al. (2004) recommended the daily intake (RDI) of polyphenols as $1 \mathrm{~g} /$ day, which means that the consumption of approximately $300 \mathrm{ml}$ of the pomegranate juice will meet the RDI for polyphenols. Results of the present study showed that a few grams of pomegranate juice and molasses (with total 
Table (3): Chemical composition of pomegranate products.

\begin{tabular}{|l|c|c|c|c|}
\hline Chemical composition & $\begin{array}{c}\text { Total sugars } \\
\mathbf{( \% )}\end{array}$ & $\begin{array}{c}\text { Reducing } \\
\text { sugars (\%) }\end{array}$ & Protein (\%) & Ash (\%) \\
\hline Pomegranate juice & $9.08 \pm 0.67^{\mathrm{e}}$ & $13.50 \pm 0.92^{\mathrm{c}}$ & $0.21 \pm 0.09^{\mathrm{c}}$ & $0.33 \pm 0.08^{\mathrm{d}}$ \\
\hline PM by heating method & $43.29 \pm 2.69^{\mathrm{a}}$ & $20.56 \pm 1.75^{\mathrm{a}}$ & $0.37 \pm 0.11^{\mathrm{b}}$ & $2.65 \pm 0.33^{\mathrm{a}}$ \\
\hline PM by rotary with sugar & $34.15 \pm 2.24^{\mathrm{c}}$ & $16.87 \pm 1.53^{\mathrm{b}}$ & $0.32 \pm 0.09^{\mathrm{b}}$ & $1.54 \pm 0.29^{\mathrm{b}}$ \\
\hline PM by rotary without sugar & $25.15 \pm 1.83^{\mathrm{d}}$ & $19.87 \pm 1.82^{\mathrm{a}}$ & $0.27 \pm 0.08^{\mathrm{c}}$ & $1.53 \pm 0.19^{\mathrm{b}}$ \\
\hline Pomegranate jam & $40.73 \pm 2.55^{\mathrm{b}}$ & $13.06 \pm 1.46^{\mathrm{c}}$ & $0.59 \pm 0.26^{\mathrm{a}}$ & $1.37 \pm 0.17^{\mathrm{c}}$ \\
\hline L.S.D. & 2.18 & 1.84 & 0.17 & 0.15 \\
\hline
\end{tabular}

*PM = pomegranate molasses produced.

*Numbers in the same column with the same letters were not significantly different at $\mathrm{P}<0.05$.

Table (4): Mineral composition of pomegranate products $(\mathrm{mg} / 100 \mathrm{~g})$ dry weight.

\begin{tabular}{|l|c|c|c|c|}
\hline \multicolumn{1}{|c|}{ Mineral composition } & Fe & Ca & Mg & K \\
\hline Pomegranate juice & $1.36 \pm 0.25^{\mathrm{d}}$ & $23.3 \pm 1.34^{\mathrm{d}}$ & $26.12 \pm 1.30^{\mathrm{d}}$ & $86.35 \pm 3.69^{\mathrm{e}}$ \\
\hline PM by heating method & $13.57 \pm 0.70^{\mathrm{c}}$ & $68.99 \pm 4.03^{\mathrm{b}}$ & $38.57 \pm 1.60^{\mathrm{c}}$ & $143.52 \pm 16.73^{\mathrm{c}}$ \\
\hline PM by rotary with sugar & $16.64 \pm 1.34^{\mathrm{b}}$ & $69.20 \pm 4.67^{\mathrm{b}}$ & $45.96 \pm 1.74^{\mathrm{b}}$ & $169.55 \pm 19.60^{\mathrm{b}}$ \\
\hline PM by rotary without sugar & $19.47 \pm 1.63^{\mathrm{a}}$ & $82.89 \pm 4.96^{\mathrm{a}}$ & $51.10 \pm 2.04^{\mathrm{a}}$ & $183.47 \pm 18.90^{\mathrm{a}}$ \\
\hline Pomegranate jam & $12.98 \pm 0.92^{\mathrm{c}}$ & $53.64 \pm 3.44^{\mathrm{c}}$ & $39.96 \pm 1.68^{\mathrm{c}}$ & $98.37 \pm 3.84^{\mathrm{d}}$ \\
\hline L.S.D. & 2.13 & 6.45 & 3.50 & 10.76 \\
\hline
\end{tabular}

*PM = pomegranate molasses produced.

*Numbers in the same column with the same letters were not significantly different at $\mathrm{P}<0.05$.

Table (5): Polyphenols, total flavonoids and antioxidant values of pomegranate products.

\begin{tabular}{|l|c|c|c|}
\hline \multicolumn{1}{|c|}{ Characters } & $\begin{array}{c}\text { Total Polyphenols } \\
(\mathbf{m g} / \mathbf{1 0 0} \mathbf{g})\end{array}$ & $\begin{array}{c}\text { Total flavonoids } \\
(\mathbf{m g} / \mathbf{1 0 0} \mathbf{~ g})\end{array}$ & DPPH (\%) \\
\hline Pomegranate juice & $7.82 \pm 0.35^{\mathrm{c}}$ & $39.99 \pm 3.53^{\mathrm{b}}$ & $81.90 \pm 5.87^{\mathrm{b}}$ \\
\hline PM by heating method & $5.27 \pm 0.14^{\mathrm{d}}$ & $27.04 \pm 3.19^{\mathrm{d}}$ & $65.50 \pm 4.81^{\mathrm{c}}$ \\
\hline PM by rotary with sugar & $12.62 \pm 0.44^{\mathrm{b}}$ & $37.19 \pm 3.04^{\mathrm{b}}$ & $92.15 \pm 5.56^{\mathrm{a}}$ \\
\hline PM by rotary without sugar & $18.93 \pm 0.63^{\mathrm{a}}$ & $44.71 \pm 3.54^{\mathrm{a}}$ & $94.20 \pm 6.86^{\mathrm{a}}$ \\
\hline Pomegranate jam & $13.64 \pm 0.56^{\mathrm{b}}$ & $37.47 \pm 3.54^{\mathrm{b}}$ & $82.60 \pm 4.39^{\mathrm{b}}$ \\
\hline L.S.D. & 1.42 & 3.52 & 5.18 \\
\hline
\end{tabular}

*PM = pomegranate molasses produced.

*Numbers in the same column with the same letters were not significantly different at $\mathrm{P}<0.05$.

flavonoids and phenolic contents of $39.99 \pm 3.53$ $\mathrm{mg} / 100 \mathrm{~g}$ and $18.93 \pm 0.63 \mathrm{mg} / 100 \mathrm{~g}$, respectively), are able to make a significant contribution to the total daily intake of dietary phenols in the human diet.

\subsection{Biological studies}

3.2.1. Effect of pomegranate products on liver enzyme activities and antioxidative status in rats

Data presented in Table (6) show the effect of pomegranate products on the activity of liver marker enzymes (alanine aminotransferase (ALT) and aspartate aminotransferase (AST)) as well as glutathione peroxidase (GPx) as a biomarker of oxidative status in rats. Liver enzymes (ALT and AST) were not significantly different at zero time between control and pomegranate product groups and during the experimental period for the control rat group. A significant decrease in ALT and AST activities was observed at the end of the experimental period for pomegranate products fed rats than that at zero time. The highest decrease was achieved by feeding rats on pomegranate molasses produced by rotary without sugar compared with the other groups. Meanwhile, there were non - significant differences between other 
pomegranate products at the end of the experimental period for ALT activity. AST activity was not statistically different between pomegranate juice and molasses produced by heating groups but it was significantly different for pomegranate molasses produced by rotary with sugar and jam products which were not significantly different compared to- each other. Kaur et al. (2006) evaluated antioxidant and hepatoprotective activities of pomegranate flowers extract in vivo and it was found to exhibit a potent protective activity in acute oxidative stress in tissue injury in animal model such as hepatotoxicity in mice. The antioxidant capacity is probably responsible for the hepatoprotective property of pomegranate extract. The increase in the activity of liver marker enzymes in serum is mainly due to the leakage of these enzymes from the liver cytosol into the blood stream.

From the data presented in Table (6) it could be observed that, glutathione peroxidase activity (GPx) significantly increased in all pomegranate product groups compared with the control group. The highest increase was achieved by feeding on pomegranate molasses produced by rotary without sugar group $(11.75 \%)$ followed by pomegranate molasses with sugar group (7.81\%). Feeding healthy mice on pomegranate juice for 28 days resulted in a protective effect of antioxidative enzymes including glutathione peroxidase (GPx). Also. The administration of pomegranate pulp juice $(250 \mathrm{ml} / \mathrm{d})$ to healthy humans for 28 days increased plasma antioxidant capacity and decreased plasma carbonyl content (Faria et al., 2007 and Guo et al., 2008). The production of reactive oxygen species (ROS) was strongly diminished in the presence of pomegranate molasses but less in the presence of juice. The effect of molasses or juice was dose dependent of the product used. Thus, the strong antioxidant substances found in molasses are acting as reactive oxygen species scavengers. SOD activity increased significantly in the group of mice given molasses, but slightly in the group given juice. The phenolic core can act as a buffer and capture electrons from ROS to render them less reactive. Polyphenols can interfere with the cellular detoxification systems such as SOD, catalase and glutathione peroxidase (Mounayar et al., 2012).

\subsubsection{Effect of pomegranate products on serum} iron, hemoglobin and blood picture in rats

Table (7) shows the effect of pomegranate juice, molasses and jam on serum iron levels and hemoglobin concentrations as well as red blood cells, white blood cells and platelets counts in the blood at the experimental rats. Serum iron levels were significantly increased as a result of feeding on different pomegranate products compared with either the control rats or pomegranate product groups at zero time. The highest increase in serum iron levels was recorded for pomegranate molasses produced by rotary without sugar followed by pomegranate jam groups. There were non significant differences in iron levels between pomegranate juice, molasses produced by rotary with sugar and jam groups.

While pomegranate molasses produced by heating method were statistically different compared with other groups. Also, hemoglobin concentration showed a significant increase in groups of rats fed on pomegranate products with the highest increase achieved by using pomegranate molasses produced by rotary without sugar and with sugar groups (16.91\% and $16.18 \%$, respectively). The lowest increase in hemoglobin concentration was noticed for the group fed on pomegranate jam (3.68\%).

Red blood cells, white blood cells and platelets counts were significantly increased by feeding on different pomegranate products compared with the control and also between pomegranate product groups at zero time and at the end of the experimental period. Pomegranate molasse groups without and with sugar were not significantly different but achieved the highest counts for red blood cells and white blood cells, respectively. All pomegranate products were found to improve blood picture measurements in healthy rats with the highest records achieved by using pomegranate molasses produced by rotary without sugar. The present results in Table (7) of serum iron and hemoglobin values as well as RBCs count confirmed each other.

The mechanisms by which chronic synthesis of

the red cell pigment heme involve at least two enzymes, the first one in the cytoplasm (deltaamino leuvinic acid) at the beginning of heme synthesis and the second enzyme in mitochondrial (ferrochelatase) at the end of heme synthesis. Ferritin is both a very efficient iron trap and a readily an available source of iron for metabolic requirements and for the formation of hemoglobin and other heme proteins. The minute concentration of ferritin in the serum is an indicator of body storage iron. Liver injury results in release of relatively enormous amounts of ferritin into plasma, resiging the serum ferritin concentration and serum iron concentration several hundered times (shibutani et al., 2001). 
Table (6): Effect of pomegranate products on liver marker enzymes and antioxidative status in the experimental rats.

\begin{tabular}{|l|c|c|c|c|c|c|}
\hline \multirow{2}{*}{ Groups } & \multicolumn{2}{|c|}{ ALT (IU/L) } & \multicolumn{2}{c|}{ AST (IU/L) } & \multicolumn{2}{c|}{ GPx (nmol/ml) } \\
\cline { 2 - 7 } & Zero & End & Zero & End & Zero & End \\
\hline Control rats & $24.5^{\mathrm{a}}$ & $24.3^{\mathrm{a}}$ & $29.1^{\mathrm{a}}$ & $28.5^{\mathrm{a}}$ & $243.6^{\mathrm{a}}$ & $248.4^{\mathrm{d}}$ \\
\hline Pomegranate juice & $24.4^{\mathrm{a}}$ & $23.1^{\mathrm{b}}$ & $28.5^{\mathrm{a}}$ & $25.5^{\mathrm{c}}$ & $240.9^{\mathrm{a}}$ & $261.9^{\mathrm{b}}$ \\
\hline PM by heating method & $24.3^{\mathrm{a}}$ & $23.5^{\mathrm{b}}$ & $28.3^{\mathrm{a}}$ & $24.7^{\mathrm{cd}}$ & $241.7^{\mathrm{a}}$ & $266.7^{\mathrm{b}}$ \\
\hline PM rotary without sugar & $24.6^{\mathrm{a}}$ & $21.4^{\mathrm{c}}$ & $28.3^{\mathrm{a}}$ & $23.3^{\mathrm{d}}$ & $240.5^{\mathrm{a}}$ & $277.6^{\mathrm{a}}$ \\
\hline PM by rotary with sugar & $24.2^{\mathrm{a}}$ & $23.4^{\mathrm{b}}$ & $28.4^{\mathrm{a}}$ & $26.4^{\mathrm{b}}$ & $241.3^{\mathrm{a}}$ & $267.8^{\mathrm{b}}$ \\
\hline Pomegranate jam & $24.5^{\mathrm{a}}$ & $23.2^{\mathrm{b}}$ & $29.0^{\mathrm{a}}$ & $26.7^{\mathrm{b}}$ & $242.5^{\mathrm{a}}$ & $259.5^{\mathrm{c}}$ \\
\hline L.S.D. & \multicolumn{2}{|c|}{0.74} & \multicolumn{3}{c}{0.88 .51} \\
\hline
\end{tabular}

*PM = pomegranate molasses produced.

*Numbers in the same column with the same letters were not significantly different at $\mathrm{P}<0.05$.

Table (7): Effect of pomegranate products on serum iron, hemoglobin and blood picture in rats.

\begin{tabular}{|c|c|c|c|c|c|c|c|c|c|c|}
\hline \multirow[t]{2}{*}{ Groups } & \multicolumn{2}{|c|}{$\begin{array}{l}\text { Serum iron } \\
\text { levels }(\mu \mathrm{g} / \mathrm{dl})\end{array}$} & \multicolumn{2}{|c|}{$\begin{array}{l}\text { Hemoglobin } \\
\text { concentrations } \\
(\mu \mathrm{g} / \mathrm{dl})\end{array}$} & \multicolumn{2}{|c|}{$\begin{array}{c}\text { Red blood cells } \\
\text { X10 } \\
\text { count }\end{array}$} & \multicolumn{2}{|c|}{$\begin{array}{l}\text { White blood } \\
\text { cells } \times 10^{3} \text { count }\end{array}$} & \multicolumn{2}{|c|}{$\begin{array}{l}\text { Platelets } \\
\text { x10 }^{3} \text { count }\end{array}$} \\
\hline & Zero & End & Zero & End & Zero & End & Zero & End & Zero & End \\
\hline Control rats & $90.0^{\mathrm{a}}$ & $92.5^{\mathrm{d}}$ & $12.91^{\mathrm{a}}$ & $13.40^{\mathrm{c}}$ & $4.6^{\mathrm{a}}$ & $4.7^{\mathrm{c}}$ & $12.0^{\mathrm{a}}$ & $12.3^{\mathrm{c}}$ & $329.1^{\mathrm{a}}$ & $340.4^{c}$ \\
\hline Pomegranate juice & $88.5^{\mathrm{a}}$ & $106.5^{\mathrm{b}}$ & $13.02^{\mathrm{a}}$ & $14.50^{\mathrm{b}}$ & $4.4^{\mathrm{a}}$ & $5.8^{\mathrm{b}}$ & $12.2^{\mathrm{a}}$ & $12.9^{\mathrm{b}}$ & $330.3^{\mathrm{a}}$ & $369.6^{\mathrm{b}}$ \\
\hline PM by heating method & $89.2^{\mathrm{a}}$ & $99.6^{\mathrm{C}}$ & $12.87^{\mathrm{a}}$ & $14.80^{\mathrm{b}}$ & $4.3^{\mathrm{a}}$ & $6.2^{\mathrm{b}}$ & $11.9^{\mathrm{a}}$ & $13.3^{\mathrm{b}}$ & $331.7^{\mathrm{a}}$ & $365.3^{\mathrm{b}}$ \\
\hline PM by rotary without sugar & $91.5^{\mathrm{a}}$ & $114.7^{\mathrm{a}}$ & $13.08^{\mathrm{a}}$ & $15.90^{\mathrm{a}}$ & $4.5^{\mathrm{a}}$ & $6.8^{\mathrm{a}}$ & $12.1^{\mathrm{a}}$ & $14.3^{\mathrm{a}}$ & $326.5^{\mathrm{a}}$ & $397.2^{\mathrm{a}}$ \\
\hline PM by rotary with sugar & $88.3^{\mathrm{a}}$ & $108.3^{\mathrm{b}}$ & $12.90^{\mathrm{a}}$ & $15.80^{\mathrm{a}}$ & $4.6^{\mathrm{a}}$ & $6.7^{\mathrm{a}}$ & $11.8^{\mathrm{a}}$ & $14.1^{\mathrm{a}}$ & $324.1^{\mathrm{a}}$ & $371.8^{\mathrm{b}}$ \\
\hline Pomegranate jam & $90.4^{\mathrm{a}}$ & $109.5^{\mathrm{b}}$ & $12.88^{\mathrm{a}}$ & $14.10^{\mathrm{b}}$ & $4.5^{\mathrm{a}}$ & $5.9^{\mathrm{b}}$ & $12.2^{\mathrm{a}}$ & $13.4^{\mathrm{b}}$ & $328.5^{\mathrm{a}}$ & $378.6^{\mathrm{ab}}$ \\
\hline L.S.D. & \multicolumn{2}{|c|}{4.56} & \multicolumn{2}{|c|}{0.73} & \multicolumn{2}{|c|}{0.46} & \multicolumn{2}{|c|}{0.54} & \multicolumn{2}{|c|}{17.6} \\
\hline
\end{tabular}

*PM = pomegranate molasses produced.

*Numbers in the same column with the same letters were not significantly different at $\mathrm{P}<0.05$.

\subsubsection{Effect of pomegranate products on immunoglobulins in rats}

Fig. (1) shows the effect of pomegranate products on aspects of immune function (immunoglobulins: IgM and IgG) in rats. Feeding rats on different pomegranate products caused a significant increase in IgM and IgG levels with the highest increase achieved by feeding on pomegranate molasses produced by rotary without sugar followed by pomegranate molasses produced by rotary with sugar groups. IgM levels were increased by $35.25 \%$ and $27.05 \%$, while $\operatorname{IgG}$ levels were increased by $39.85 \%$ and $38.88 \%$ relative to the control, respectively. The lowest increase in $\operatorname{IgM}$ was achieved by feeding on pomegranate molasses produced by heating method $(10.65 \%)$ which was not significantly different compared with pomegranate juice and jam groups. For IgG, the lowest increase was recorded in pomegranate jam group (24.89\%) which was significantly different compared with the other groups. Feeding on pomegranate molasses produced by rotary and pomegranate juice caused an improvement in immune function in rats compared with the control group. $\operatorname{IgM}$ is frequently associated with the immune response to antigenically complex, blood porne infections agents and is used as a diagnostic screening antibody. $\operatorname{IgG}$ functions as an antiallergic factor by competing with the allergen-specific IgE to bind to the receptor on the surface of the target cells such as mast cells and basophils. Therefore, both $\operatorname{IgA}$ and $\operatorname{IgG}$ exert a preventive effect on IgE-mediated allergy and viral infections (Roche et al., 2001 and Dempsey et al., 2003).

The pro-oxidant/antioxidant balance is an important approval of the immune cell function, not only for maintaining of integrity and functionality of membrane lipids, cellular proteins and nucleic acids of the immune cell, but also for the control of signal transduction and gene expression as well. The immune cells are particularly sensitive to oxidative stress because of the rather high percentage of polyunsaturated fatty acids in their cell membranes. To overcome this problem, the immune cells usually contain higher 

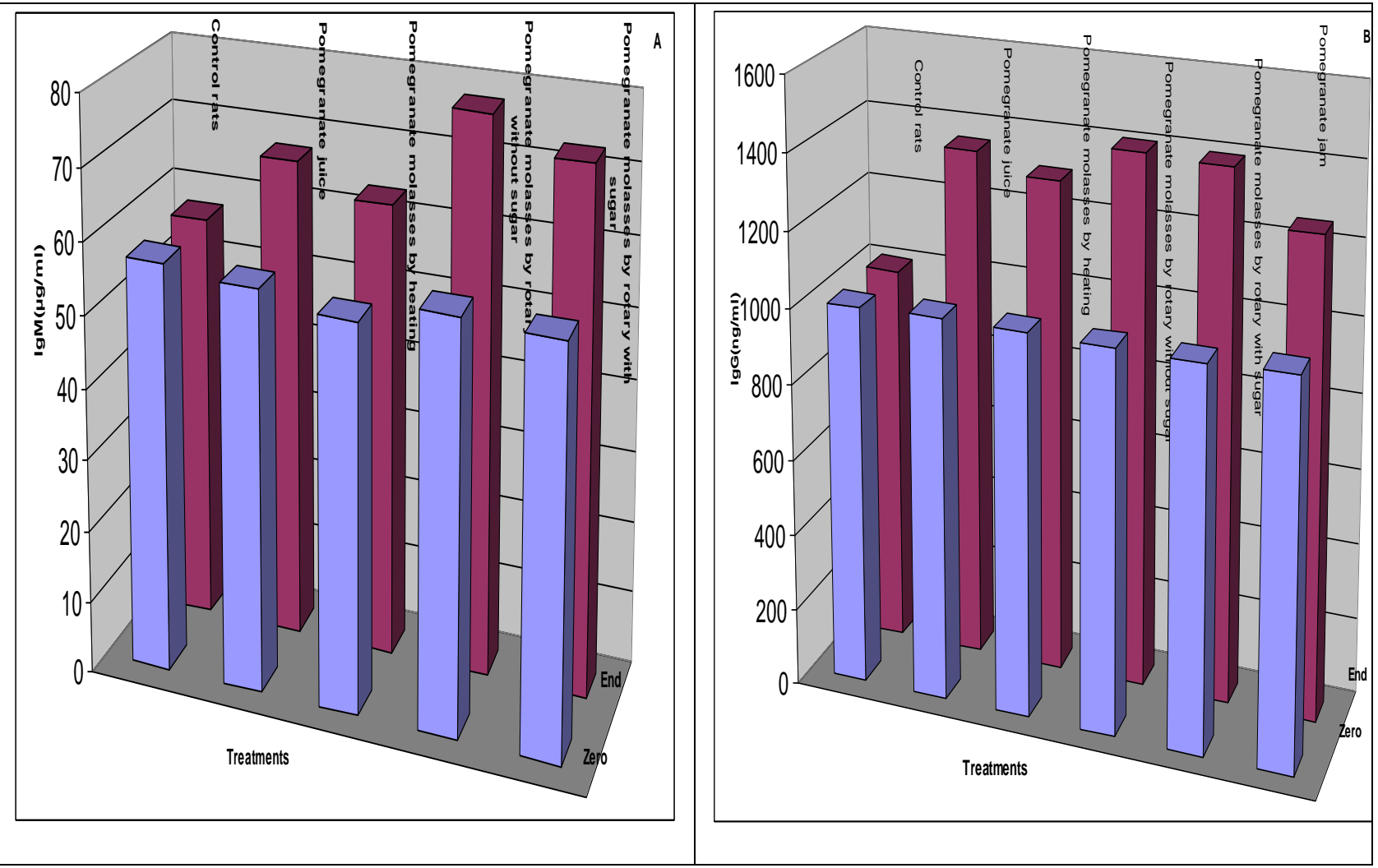

Fig(1): Effect of Pomegranate aril products on immunoglobulins.

amounts of antioxidants than the other cells. Polyphenols as dietary antioxidants may affect various aspects of the immune system by shifting pro-oxidant/antioxidant balance towards antioxidant. Immunoglobulin production may be enhanced in rats fed on quercetin. The effect on Ig production by polyphenols can be complex and class specific. Daidzein enhance $\operatorname{IgM}$ and $\operatorname{IgE}$ levels at concentrations above $10 \mu \mathrm{M}$, moreover, quercetin and luteolin enhanced medium IgE level at all concentrations tested. These effects indicate that polyphenols induce general increase in immunoglobulin concentrations (Han et al., 2002).

Pomegranate is among the richest fruit in polyphenols. It is logical to hypothesize that, fresh pomegranate juice should have a more considerable amounts of polyphenols than that found in molasses obtained after $6 \mathrm{~h}$. of heating. One can consider that high temperature should deteriorate polyphenols in molasses as severe thermal treatment can alter the bioavailability of polyphenols by decreasing the absorption of active compounds due to the formation of oxidized products. On the contrary, polyphenols in molasses were found to be four times greater than those found in the juice. Molasses has the strongest antioxidant properties in vitro compared to juice. This could indicate that, high temperature helps polyphenols to be released from pomegranate fruit cells as there is no extraction with a solvent in the preparation of pomegranate molasses (Porrini and Riso, 2008 and Visioli et al., 2011).

In conclusion ,Pomegranate molasses produced by rotary methods were found to achieve the highest quality characteristics compared with other pomegranate products of the present study. Pomegranate molasses produced by rotary without sugar recorded the highest increase in total phenol content, total flavonoids and antioxidant activity. Pomegranate molasses produced by heating method showed the lowest values for color indices and antioxidant activity as a result of severe heat treatment. Pomegranate jam achieved the highest scores for different sensory. Administration of pomegranate juice and pomegranate molasses caused an improvement in liver marker enzymes, activity as well as antioxidant status and immune functions. Therefore, pomegranate juice, molasses and jam products should be served in the human diet to obtain their nutritional benefits.

\section{REFERENCES}

Ahmed J., Shivhare U. S. and Raghavan G. S. V. (2004). Thermal degradation kinetics of anthocyanin and visual color of plum puree. 
Eur. Food Res. Technol., 218: 525-528.

Alper N., Bahceci K. S. and Acar J. (2005). Influence of processing and pasteurization on color values and total phenolic compounds of pomegranate juice. J. Food Proc. Preser., 29: 357-368.

Anonymous (2006). USDA. National Nutrient Database for Standard Reference, Release 15 August, 2002.

A.O.A.C. (2006). Official Methods of Analysis. $18^{\text {th }}$ Edition, Association of Official Agricultural Chemists. Washington, DC., USA.

Barnes K. W. (1997). Trace metal determinations in fruit, juice and juice products using an axially viewed plasma. Atomic Spectroscopy, 18: 84-101.

Bergmeyer H. U. and Harder M. (1986). A colorimetric method of the determination of serum glutamic oxaloacetic and glutamic pyruvic transaminase. Clin. Biochem., 24: 481-485.

Craven P. A., Melhem M. F. and DeRubertis F. R. (1992). Thromboxane in the pathogenesis of glomerular injury in diabetes. Kidney Int., 42: 937-946.

Daret K. S. C. and Ching K.C. (1996). Glutathione peroxidase: activity and steady-state level of mRNA. In: Punchard NA, FJ Kelly, eds. Free Radicals, A Practical Approach. Oxford, New York; pp.227-231.

Deisenhammer F., Keir G., Pfausler B. and Thompson E. J. (1996). Affinity of antiGM1 antibodies in Guillain-Barre syndrome patients. J. Neuroimmunol., 66: 85-93.

Dempsey PW., Vaidya SA. and Cheng G. (2003). The art of war: Innate and adaptive immune responses. Cell Mol. Life Sci., 60: 26042621.

Duman AD., Ozgen M., Dayisoylu KS., Erbil N. and Durgac C. (2009). Antimicrobial activity of six pomegranate variaties and their relation to some of their pomological and phyto-nutrient characteristics. Molecules, 14: 1808-1817.

Fadavi A., Barzegar M., Azizi M. H. and Bayat M. (2005). Physicochemical composition of ten pomegranate cultivars (Punica granatum L.) grown in Iran. Food Sci. Technol. Int., 11(2): 113-119.

Faria A., Monteiro R., Mateus N., Azevedo S. and Calhau C. (2007). Effect of pomegranate (Punica granatum L.) juice intake on hepatic oxidative stress. Eur. J. Nutr., 46(5): 271-278.
Fawole O. A., Opara U. L. and Theron K. I. (2011). Chemical and phytochemical properties and antioxidant activities of three pomegranate cultivars grown in South Africa. Food Bioprocess. Technol., 3: 533539.

Fischer U. A., Dettmann J. S., Carle R. and Kammerer D. R. (2011). Impact of processing and storage on the phenolic profiles and contents of pomegranate (Punica granatum L.) juices. Eur. Food Res. Technol., 233: 797-816.

Gil M. I., Tomas-Barberan F. A., Hees-.Pierce, B., Holeroft D. M. and Kader A. A. (2000). Antioxidant activity of pomegranate juice and its relationship with phenolic composition and processing. J. Agric. Food Chem., 48(10): 4581-4589.

Gomez K. A. and Gomez A.A. (1984). Statistical Procedures of Agricultural Research. John Wiley and Sons, Inc., USA.

Guo C., Wei J., Yang JJ., Xu J., Pang W. and Jiang YG. (2008). Pomegranate juice is potentially better than apple juice in improving antioxidant function in elderly subjects. Nutr. Res., 28: 72-77.

Han D., Denison MS., Tachibana H. and Yamada K. (2002). Effects of estrogenic compounds on immunoglobulin production by mouse splenocytes. Biol. Pharm. Bull., 25: 12631267.

Incedayi B., Tamer CE. and Copur OU. (2010). A research on the composition of pomegranate molasses. J. Agric. Fac. Uludag Univ., 24(2): 37-47.

Jaiswal V., DerMarderosian A. and Porter JR. (2010). Anthocyanins and polyphenol oxidase from dried arils of pomegranate. Food Chem., 118: 11-16.

Karioti A., Mensah M. L. K., Fleischer T. and Saltsa H. (2004). Composition and antioxidant activity of the essential oils of Xylopia aethiopica A. leaves, stems, roots and fresh and dried fruits. J. Agric. Food Chem., 52: 8094-8098.

Kaur G., Jabbar Z., Athar M . and Alam M.S. (2006).Pomegranate floor extract possesses potent antioxidant activity and abrogates Fe-NTA- induced hepatotoxicity in mice.Food Chem. Toxicol ., 44 (7): $984-$ 993.

Lee CJ., Chen LG., Liang WL. and Wanga CC. (2010). Anti-inflammatory effects of Punica granatum L. in vitro and in vivo. Food Chem., 118: 315-322. 
Maskan M. (2006). Production of pomegranate juice concentrate by various heating methods: color degradation and kinetics. J. Food Engineer., 72: 218-224.

Melgarejo P., Salazar DM. and Artes F. (2000). Organic acids and sugars composition of harvested pomegranate fruits. Eur. Food Res. Technol., 211: 185-190.

Mena P., Viguera C., Rico J., Moreno D., Bartual J., Saura D. and Marti N. (2011). Phytochemical characterization for industrial use of pomegranate (Punica granatum L.) cultivars grown in Spain. J. Sci. Food Agric., 91: 1893-1906.

Moneim AE., Dkhil M.A. and Al-Quriashy S. (2011). Studies on the effect of pomegranate (Punica granatum) juice and peel on liver and kidney in adult male rats. J. Med. Plants Res., 5(20): 5083-5088.

Mounayar A. C., Nemer R., Yared P., Khairallah S. and Chahine R. (2012). Antioxidant and weight loss effects of pomegranate molasses. J. Appl. Pharmaceut. Sci., 2(6): 45-50.

Mousavinejad G., Emam-Djomeh Z., Rezaei K. and Khodaparast MHH. (2009). Identification and quantification of phenolic compounds and their effects on antioxidant activity in pomegranate juice of eight Iranian cultivars. Food Chem., 115: 12741278.

Orak H. (2008). Evaluation of antioxidant activity, color and some nutritional characteristics of pomegranate juice and its sour concentrate processed by conventional evaporation. Int. J. Food Sci. Nutr., 60(1): 1-11.

Patras A., Brunton AP., O'Donnel C. and Tiwari BK. (2010). Effect of thermal processing on anthocyanin stability in foods: mechanisms and kinetics of degradation. Trends Food Sci. Technol., 21: 3-11.

Poiana M., Alexa E. and Mateescu C. (2012). Tracking antioxidant properties and color changes in low-sugar bilberry jam as effect of processing, storage and pectin concentration. Chem. Central J., 6(4): 2-11.

Porrini M. and Riso P. (2008). Factors influencing the bioavailability of antioxidants in foods: A critical appraisal. Nutr. Metab. Cardiovasc. Dis., 18: 647-650.

Poyrazoglu E., Gökmen V. and Artik N. (2002). Organic acids and phenolic compounds in pomegranate grown in Turkey. J. Food Comp. Anal., 15: 567-575.

Rinaldi M., Caligiani A., Borgese R., Palla G.,
Barbanti D. and Massini R. (2013). The effect of fruit processing and enzymatic treatments on pomegranate juice composition, antioxidant activity and polyphenols content. LWT-Food Sci. Technol., xxx: 1-5.

Roche H. M., Noone E., Nugent A. and Gibney M. J. (2001). Conjugated linoleic acid: a novel therapeutic nutrient. Nutr. Res., 14: 173-187.

Rosenblat M. and Aviram M. (2006). Antioxidative properties of pomegranate: In vitro studies. In N. P. Seeram and D. Heber (Eds.), New York: Taylor and Francis Group, Pomegranates: Ancient roots to modern medicine, pp.31-43.

Saka J., Rapp I., Akinnifesi F., Ndolo V. and Mhango J. (2007). Physicochemical and organoleptic characteristics of Uapaca kirkiana and Mangiferia indica fruit products. Int. J. Food Sci. Technol., 42: 836-884.

Seeram NP., Aviram M., Zhang Y., Henning, SM., Feng L. and Heber D. (2008). Comparison of antioxidant potency of commonly consumed polyphenol-rich beverages in the United States. J. Agric. Food Chem., 56(4): 1415-1422.

Seigin R. D. (1977). Interaction of nutrition and infection: plans for future research. Am. J. Clin. Nutr., 30: 1553-1563.

Shibutani M. K., Mitsumori S., Satoh H., Hiratsuka M. and Satoch M. (2001). Plasma cadmium metallothionein, a releationship between biological exposure index and cadmium accumulation in rats renal dysfunction. J. Toxicol. Action Toxicology, 129: $157-168$.

Singelton V. R., Orthifer R. and LamuelaRaventos R. M. (1999). Analysis of total phenols and other oxidation substances and antioxidants by means of Folin-Ciocalteu reagent. Methods Enzymol., 299: 152-178.

Suh H. J., Noh D. O., Kang C. S., Kim J. M. and Lee S. W. (2003). Thermal kinetics of color degradation of mulberry fruit extract. Nahrung, 47: 132-135.

Tezcan F., Diken T., özcelik B. and Erim FB. (2009). Antioxidant activity and total phenolic, organic acid and sugar content in commercial pomegranate juices. Food Chem., 115(3): 873-877.

Vardin H. and Fenercioglu H. (2003). Study on the development of pomegranate juice processing technology: clarification of 
pomegranate juice. Nahrung, 47: 300-303.

Vardin H., Tag A., Ozen B. and Mauer L. (2008). Authentication of pomegranate juice concentrate using FTIR spectroscopy and chemometrics. Food Chem., 108: 742-748.

Visioli F. De La Lastra C. A. Lacueva C., Aviram M., Calhau C. and Cassano A. (2011). Polyphenols and human health: A prospectus. Crit. Rev. Food Sci. Nutr., 51: 524-546.

Vrhovsek U., Rigo A., Tonon D. and Mattivi F. (2004). Quantification of polyphenols in different apple varities. J. Agric. Food Chem., 52: 6532-6538.
Yang J., Martinson T. E. and Liu R. H. (2009). Phytochemical profiles and antioxidant activities of grapes. Food Chem., 116: $332-$ 339.

Yilmaz Y., Celik I. and Isik F. (2007). Mineral composition and total phenolic content of pomegranate molasses. J. Food Agric. Environ., 5(3,4): 102-104.

Zamora R., Hidalgo F. J. and Tapple A. A. (1991). Comparative antioxidant effectiveness of dietary beta-carotene, vitamin $\mathrm{E}$, selenium and coenzyme Q10 in rat erythrocytes and plasma. J. Nutr., 121: 50-56

\section{دراسات كيماوية وحيوية على بعض منتجات الرمان \\ سحر احمد عرفة \\ قسم الاغذية الخاصة و التغذية ـ معهد بحوث تكنولوجيا الاغذيةـ مركز البحوث الزر اعية ــ الجيزة- مصر.}

تستخدم ثمرة الرمان بكثرة فى الغذاء و الصناعات الغذائية ويرجع ذللك لفائدتها الغذائية الممتازة وقيمتها الصحية العالية

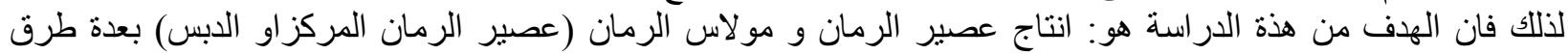

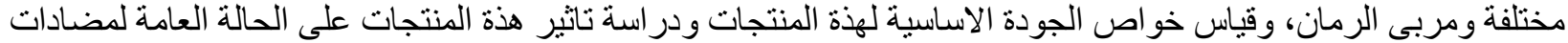

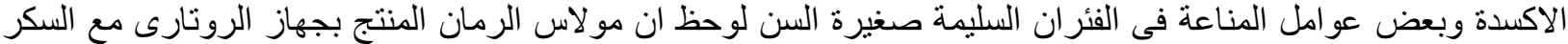

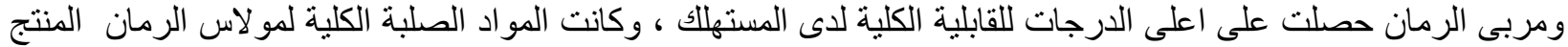

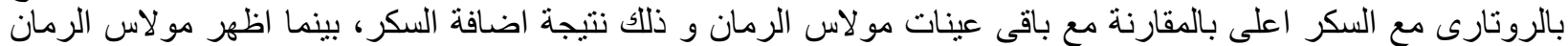

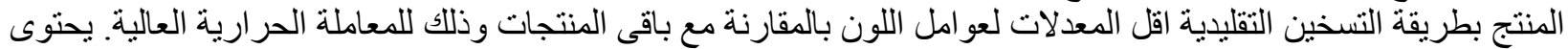

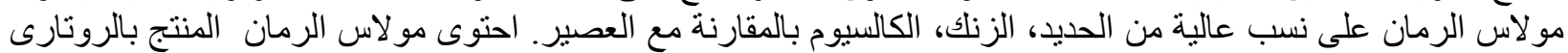

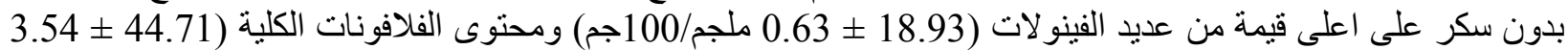

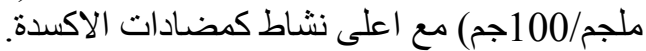

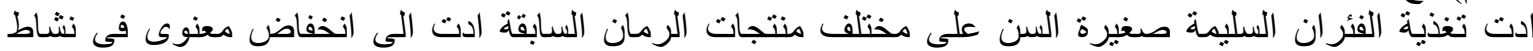

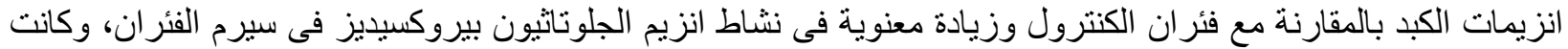

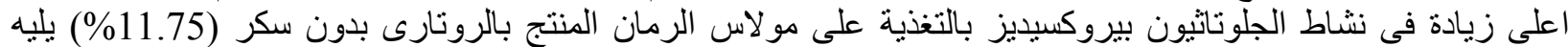

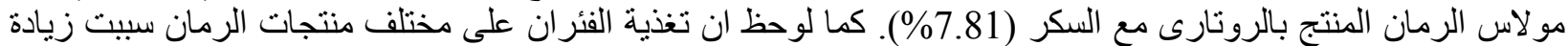

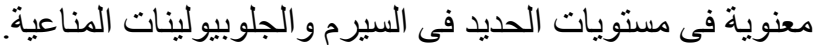

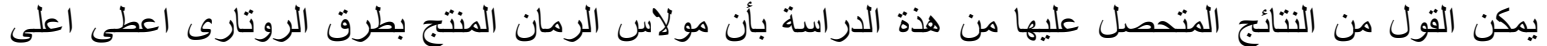

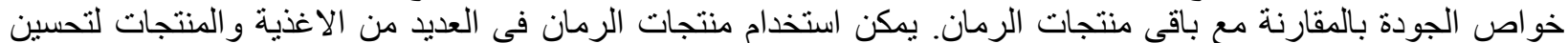

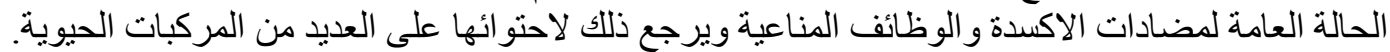

